\title{
Imperial irrigated landscapes in the Balikh Valley
}

Louise Rayne

School of Archaeology and Ancient History, University of Leicester, Leicester, UK ler14@leicester.ac.uk

This is a post-peer-review, pre-copyedit version of an article published in Water History. The final authenticated version is available online at:

\section{https://doi.org/10.1007/s12685-015-0128-8}

\begin{abstract}
This research presents the results of an interdisciplinary study which examined how increased adoption of water management technologies from the HellenisticEarly Islamic period transformed the formerly marginal and rain-fed Balikh Valley of Syria into a productive landscape. Data including CORONA satellite images, topographical models and archaeological surveys were used to identify and analyse systems of canals, qanats and tunnels. Analysis of this identified a peak in the use of irrigation in the later imperial period, especially at the time of the Early Islamic empire when the city of Raqqa attained enhanced political significance, with indications that ancient systems were able to utilise most of the available water resources in the valley. Water management activity also appears to have led to changes in the environment of the Balikh, such as the formation and drainage of marshes and rerouting of existing hydraulic networks.
\end{abstract}

\section{Introduction}

Archaeological excavation and survey have been used to investigate the patterns and distribution of settlement over time in the Balikh Valley of Syria (see Fig. 1). The present research has combined these with technologies of GIS (Geographical Information Systems) and remote sensing in order to examine how activity in the Balikh was supported by water management. This paper examines how under imperial/caliphal administration, we do not only see the imposition of large-scale 
irrigation systems, but also how the unintended consequences of such systems result in the creation of new ecological and economic niches.

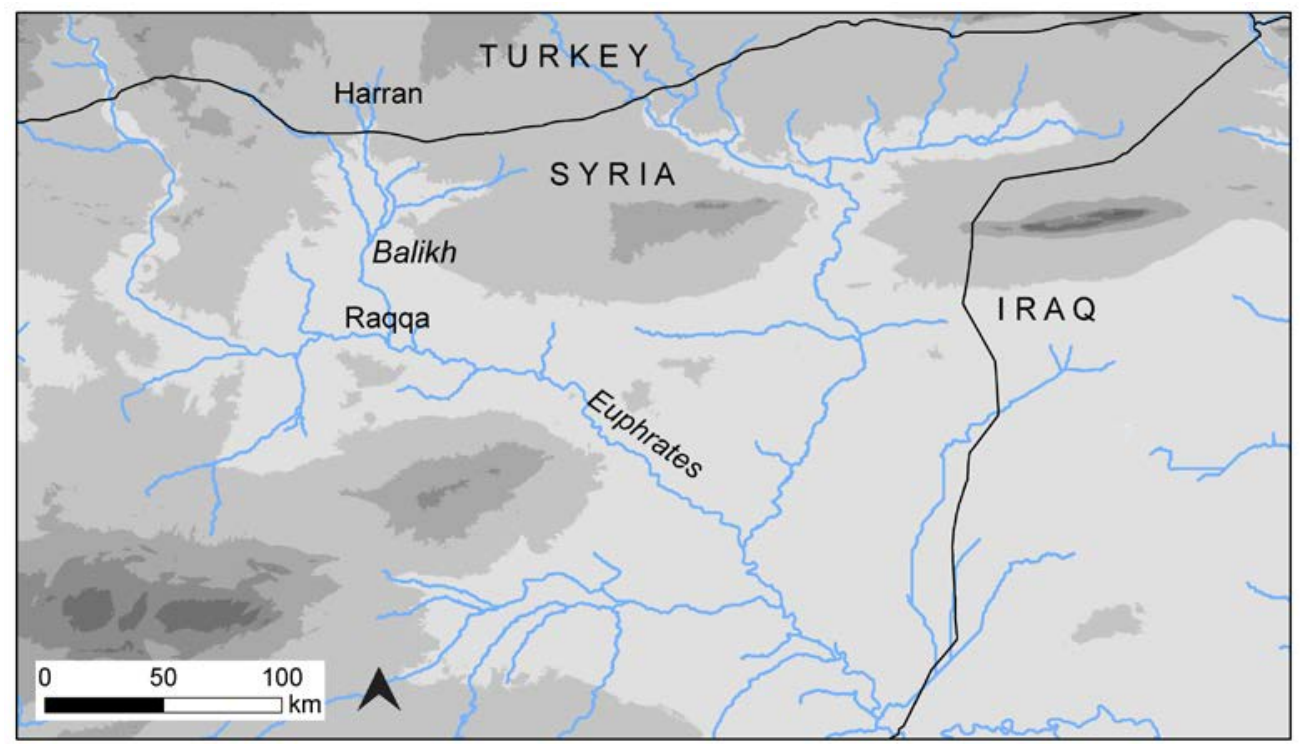

Fig 1: Location of the Balikh valley in Syria.

Mallowan's description of the Balikh Valley as a marshy backwater (1946, p114) is often quoted in order to highlight the contradiction between the concept of the area as a 'backwater' and the complex patterns of settlement identified by more recent archaeological work (e.g. see Hritz 2013a; De Jong 2011). However, the landscape and landuse aspects of this quote are also interesting. Today, the landscape of the Balikh reflects recent large-scale changes which accommodated intensive cultivation using irrigation water brought from much further upstream. The landscape of the Balikh as it was in the earlier $20^{\text {th }}$ century (pre 1980s) was very different, and represented "layers" of former anthropogenic environments. At this time, travellers and archaeologists described an environment of branching channels and inaccessible swamps (e.g. see Mallowan 1946), and landuse in the form of pastoralism and dry farming (see Sykes 1915).

The early $20^{\text {th }}$ century landscape represented the end of a long sequence of phases of agricultural activity, well preserved in its final stages in 1960s satellite images which were taken before the more recent changes took place. Archaeological survey and excavation identified a landscape of tells (mounded sites) in the Bronze Age (Curvers 1991) changing to a predominance of smaller, more dispersed sites in the Iron Age and later (Wilkinson 1998). The significance of the region in later periods, 
primarily the Early Islamic, has also been discussed (e.g. see Bartl 1994). Raqqa, in the south of the Balikh Valley, was the temporary capital of the Abbasid Empire under the caliph Harun Al Rashid (786-809 AD), and because the valley formed the city's hinterland it experienced an enhanced political, strategic and economic status during this period.

The present research examines how increased adoption of water management technologies from the Hellenistic-Early Islamic period transformed a formerly marginal and rain-fed area into a productive landscape. Irrigation has already been recognised as a feature of the later periods, especially the Early Islamic (see Wilkinson 1998; Wilkinson and Rayne 2010). The current project has enhanced the existing published data through the examination of CORONA satellite images, allowing previously undetected channels to be identified and for irrigation systems to be mapped throughout the whole valley.

This paper also assesses how these changes may have led to the formation of specific environmental niches which persisted as geomorphological traces into the $20^{\text {th }}$ century. The concept of 'human niche construction' explains the ability of humans to modify their environments (e.g. see Kendal et al 2011). It is possible that such processes were also in operation at 'imperial' scales, creating landscapes which persisted up until modern mechanized agriculture erased them.

\section{Methods and data}

This work adopted an interdisciplinary methodology, incorporating remote sensing data with evidence from archaeological surveys to map features of ancient water management in the Balikh. In order to assess to what extent the landscape of the Balikh was modified in the past, the region as a whole had to be mapped, both before and after the changes that took place from the 1980s occurred. At this time, farming moved away from traditional rain-fed farming (e.g. see Hole and Zaitchik 2006, p145; Beaumont 1996, p137) to large-scale modern irrigation (Ababsa 2011, p85).

Remote sensing provides ideal tools for recording relict hydrology, offering a largescale perspective relatively quickly and cheaply. By using 1960s CORONA images, it 
was also possible to view the landscape before the changes caused by more recent agriculture and urbanisation had occurred. These panchromatic images are of a relatively high resolution $(2-5 \mathrm{~m})$ and also had a large spatial coverage, properties which archaeological studies are increasingly making use of (e.g. see Donoghue et al. 2002). Later imagery such as IKONOS was also examined to provide a perspective on the modern landscape, but it was found that most of the features of archaeological interest were no longer present.

In order to understand how the pre-1980s drainage systems functioned, topographic information was needed. This was obtained using digital elevation models (DEMs). The freely available SRTM (Shuttle Radar Topography Mission) and ASTER (Advanced Spaceborne Thermal Emission and Reflection Radiometer) were used to model the modern drainage network and to distinguish natural from artificial channels. At relatively coarse resolutions ( $90 \mathrm{~m}$ and $30 \mathrm{~m}$ respectively), however, the morphology of individual canals could not be discerned using these data. Higherresolution DEMs of selected areas were produced using the technique of CORONA photogrammetry. The CORONA satellite $\mathrm{KH}-4 \mathrm{~B}$ was equipped with two panoramic cameras, allowing heights to be calculated based on the relationship between the flying height of the satellite and the intersecting angles between the two images. Resolutions of up to $10 \mathrm{~m}$ were obtained using this method.

Detailed irrigation networks were mapped using these combined data. Firstly, canals were digitised in ArcMap from visual interpretation of the CORONA images. DEMs were used to verify whether the mapped linear features were ancient canals because canals tended to follow the natural contours of the landscape. This made it possible to extract further information about their functions. Such canals were further contextualised using information from historical sources (e.g. see Le Strange 1930), existing archaeological surveys from which sites were located (see Wilkinson 1998; Wilkinson, unpublished data; Curvers 1991; Bartl 1994) and a field visit in July 2010. 


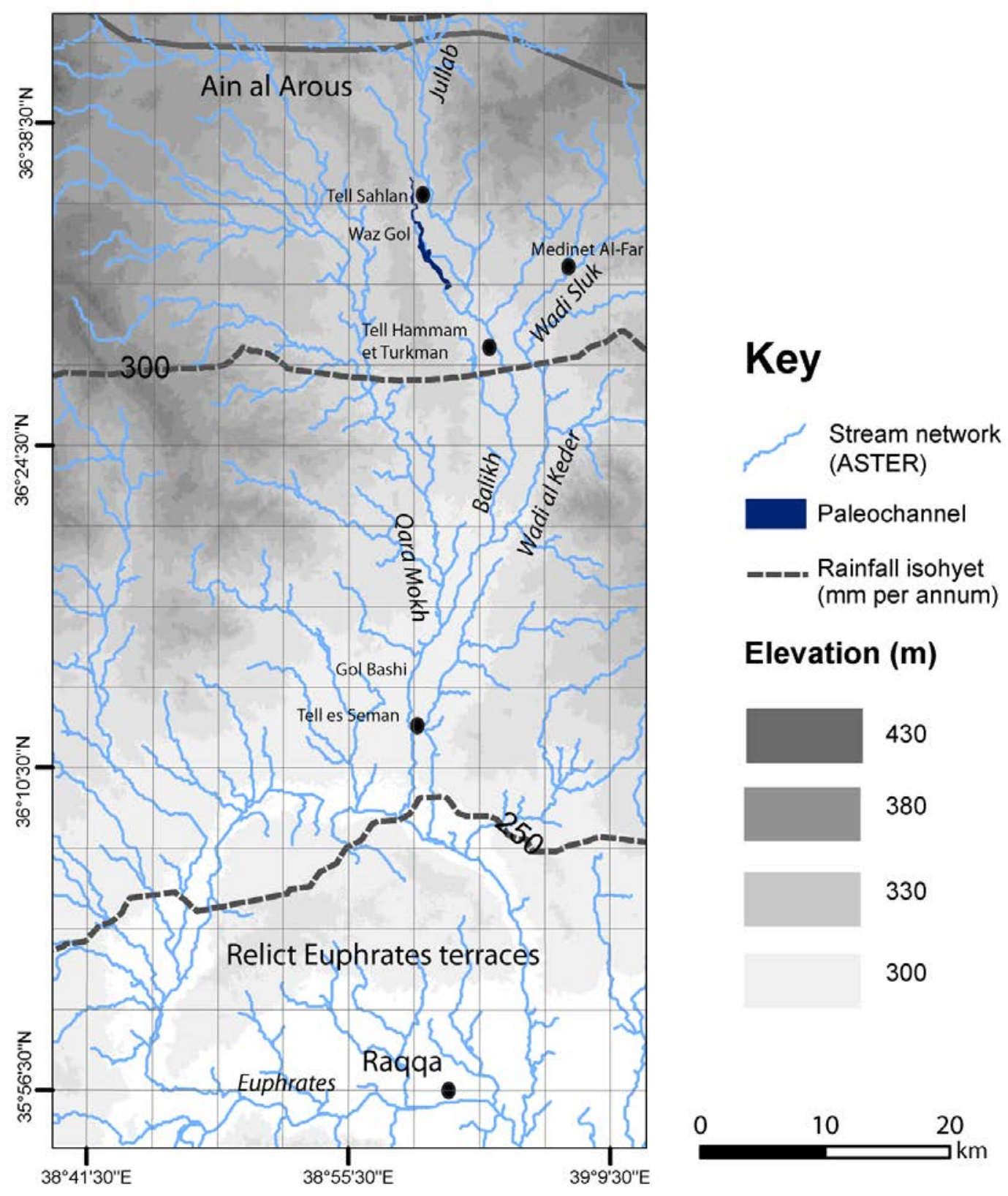

Fig.2 The Balikh Valley and stream networks. The rainfall isohyets were produced using rain gauge data from GPCC (Global Precipitation Climatology Centre, see Schneider et al 2014; Becker et al 2013).

\section{Irrigation in the Balikh}

The Balikh stands out as an area of particularly complex and intensive relict irrigation comprising multiple phases and layers. While obtaining dating information from water 
systems can be difficult, many channels in the Balikh can be dated either by existing excavation or survey data or by association with features of known date. For example, a tunnel in the south of the Balikh had a clear link with archaeological features associated with a palatial complex of Abbasid Raqqa. Also in other parts of the Balikh, a relative stratigraphy of channels could be discerned. For example, a canal near Raqqa had been interpreted as Abbasid (Toueir 1983 p298; Toueir 1990 p217; Heidemann 2006 p36) but on examination of the CORONA images and on visiting the Abbasid site complex of Heraqlah in 2010, it was found that the canal truncated Heraqlah, demonstrating that the canal clearly post-dated the site (Wilkinson and Rayne 2014, Fig.4 shows the sequence).

Irrigation systems are comprised of several parts or zones. A large-scale canalbased system will consist of an abstraction/extraction point where water will be taken off (generally from a permanent water source), a main canal, and networks of branching offtakes (including submain canals and lateral channels) which deliver water from the main canal to the fields. The main transport canals tend to have the lowest gradients (for example between 0.5-2.5\%, see Zimmerman 1966; Kruse et al 1983), because these need to convey water over as long a distance as possible. Depending on their preservation in the 1960s, the component parts of an irrigation system can be identified through examination of CORONA images.

The evidence for past water management systems in the Balikh can be divided into four main groups;

1. Bronze Age (including Middle Assyrian)

2. Iron Age (Neo-Assyrian)

3. Hellenistic-Byzantine

4. Early Islamic

Bronze Age

There is some evidence for pre-Hellenistic irrigation in the Balikh. Archaeobotanical data suggest cereal farming in the $5^{\text {th }}$ millennium B.C. near Tell Hammam et 
Turkman, which may indicate irrigation (Akkermans 1993 p22; Bottema 1989 p14). Akkermans suggests that by the $2^{\text {nd }}$ millennium, small-scale water management involving simple diversion from the Balikh to the fields using dams could have been practised (Akkermans 1993 p206).

The earliest clear evidence for water management in the Balikh is documentary. Bronze Age texts from Mari refering to a conflict over water abstraction between Tutul (Tell Bia'a), in the south of the Balikh, and an upstream site named Zalpah (perhaps modern Tell Hammam et-Turkman (e.g. see Villard 1987; Dossin 1974; Wilkinson 1998). Texts from the Middle Assyrian site of Sabi Abyad also refer to irrigation; a letter mentions a water management feature which controlled excess water, interpreted by Wiggerman (2000 p177) as a dike. Also based on the textual evidence, an arable area of about 1440 ha was suggested for the site (ibid. p181) which was a regional centre controlling the surrounding farmlands (see Wiggerman 2000 p172). While there is so far no clear archaeological evidence to match these texts, a group of Bronze Age sites in the Sabi Abyad area on the same alignment as the later Nahr Al Abbara canal may have been aligned along a Late Bronze Age canal. It is therefore possible that the Early Islamic Nahr al Abbara (discussed below) represents later irrigation activity overlying earlier, Bronze Age canals.

Different phases of channels themselves in this area can also be identified in the CORONA image. Examination of the CORONA images reveals two possible abstraction zones from which channels originate; one originating from the Balikh near Tell Sahlan, another flowing from the Wadi Sluk, past Medinet al Far (see Fig.2). It is possible to suggest that the water management represented in the textual evidence (e.g. Wiggerman 2000) could refer to an early phase of some of these channels, while the Early Islamic canals represent a later phase of irrigation on similar alignments.

\section{Iron Age}

Again, clear archaeological evidence for Neo-Assyrian water management is lacking, but instead information is supplied by textual sources. The Neo-Assyrian document known as the Harran census (see Fales and Postgate 1995; Johns 1901) describes 
the region around Harran (see Fig. 1 for location), possibly including part of the Balikh valley. This source frequently refers to the presence of cisterns at individual farms, reflecting small-scale, localised water management, possibly for domestic use. These features would have been used to collect water at times when it was more abundant, storing it for times of scarcity.

\section{Hellenistic-Byzantine}

Although data for earlier water abstraction is based on textual sources, there is archaeological evidence to support canal-based irrigation from the Hellenistic period onwards. Wilkinson (1998 p71) excavated a section in a segment of canal flowing near Tell Sahlan. This channel fades out, although there is a line of gullies which may indicate its course, but resumes downstream and terminates near Tell Hammam et Turkman. Wilkinson's excavations returned a radiocarbon date of $1380 \pm 70$ BP (Beta78543 , c. AD 570 \pm 70 , see Wilkinson 1998 p71), suggesting that the canal was used in the Byzantine-Early Islamic periods, although the ceramics from the fills suggested use extending back to the Hellenistic.

The canal is a large feature with prominent upcast banks; Wilkinson (1998, p80) suggests that the Sahlan segment measured up to $6.5 \mathrm{~m}$ wide with a depth of $1 \mathrm{~m}$ (ibid. p80), with a possible discharge of $7.8 \mathrm{cu} \mathrm{m} / \mathrm{sec}$. The Hammam segment downstream was examined by the present study using DEMs produced from CORONA stereopairs (e.g. Fig. 3). The $10 \mathrm{~m}$ resolution DEM gives an impression of the dimensions of the eroded and partially infilled canal in the 1960s, when it measured at least $5 \mathrm{~m}$ in width from bank to bank, and at least $0.5 \mathrm{~m}$ in depth. Even in this eroded and infilled state, the canal was a significant feature, comparable to the Sahlan segment. Fieldwork undertaken in 2010 confirmed that it has since been removed from the landscape. 


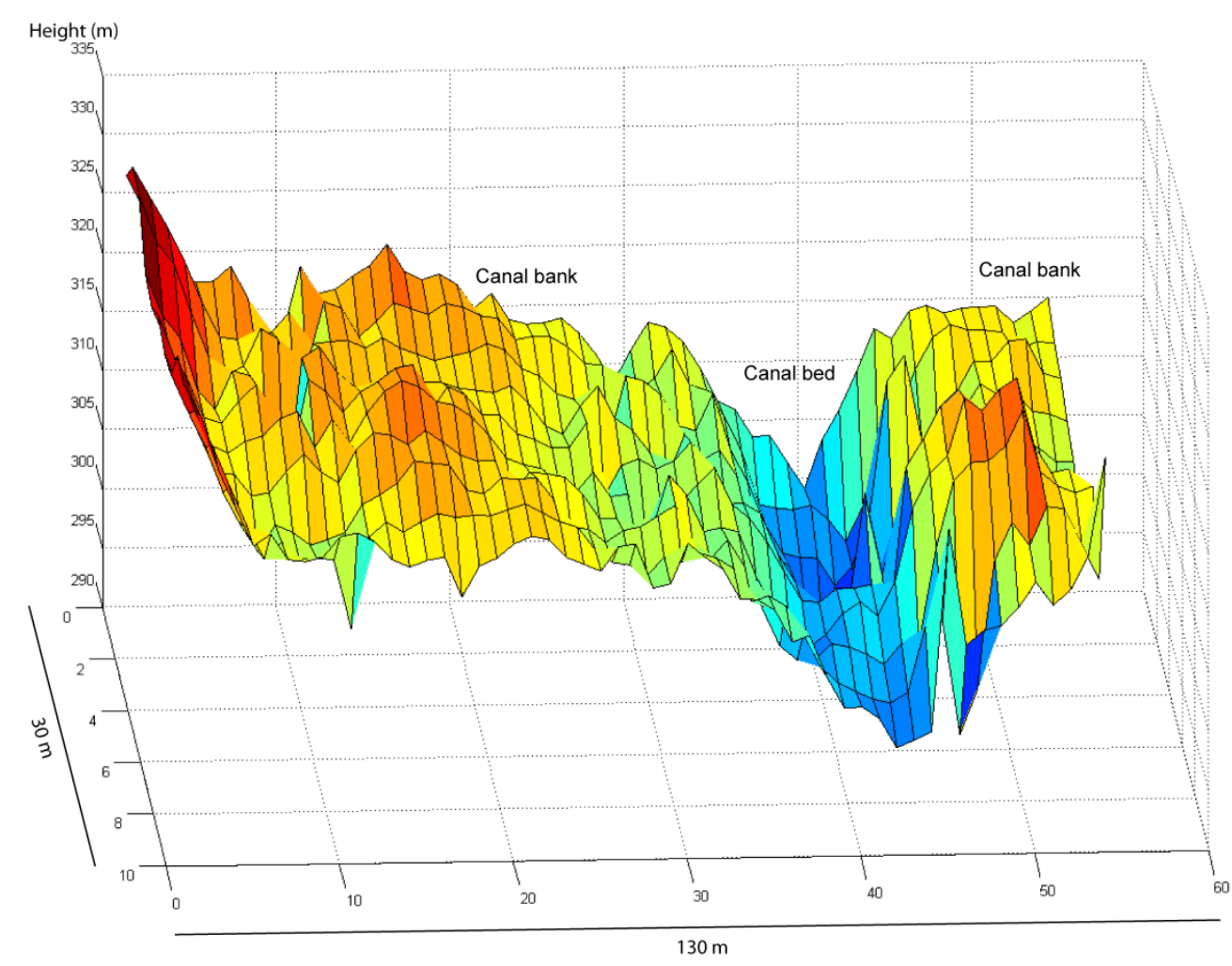

Fig.3 Filtered $3 D$ surface of the Hammam canal created using the CORONA DEM. The surface was created by taking points at $3 \mathrm{~m}$ intervals along transects of $130 \mathrm{~m}$ in length.

Given their size and height above the fields, the two segments of channel presumably represent a main irrigation canal, forming the 'transport zone' of this system. The canal appears to have abstracted from close to Tell Sahlan and fades out close to the Balikh south of Tell Hammam et Turkman, where it may have terminated. The lateral canals which would have diverted water from this canal to the fields are not identifiable.

Another Hellenistic canal system is visible to the south of where the SahlanHammam canal fades out. Wilkinson mapped segments of this system closer to the sites of Mounbateh and Tell Sheikh Hassan (e.g. see Wilkinson 1998 p66) and identified it as Hellenistic, based on the surface survey of associated sites (Wilkinson 1998 p77). The CORONA images show that these channels are joined to a very long main canal, which flows for up to $20 \mathrm{~km}$, closely following the alignment of the Balikh. This either abstracted from the Balikh south of the Sahlan-Hammam canal, or was part of the same system. In the latter case this would make its abstraction point the 
Balikh near Tell Sahlan. The irrigated zone associated with this system is identifiable, through a pattern of offtakes, which are flanked by Hellenistic sites (see Figure 4).

This irrigation system makes efficient use of natural topography. The main canal runs along an area of slightly higher ground at the edge of the Balikh floodplain, at a shallow gradient, while the lateral canals branch off this ground, gaining more elevation (down a slope of up to $0.4 \%$ ). One set of channels follows the ridge and drains into the Qara Mokh, while other branches flow south-east and drain into the Balikh. Based on flow calculations Wilkinson suggested that between 1760-7800 ha could have been irrigated by the Sahlan Hammam canal (Wilkinson 1998 p82). On examination of the layout of channels in the central Balikh area in the CORONA, the area served by the lateral canals of this system (representing an irrigation zone) is about 1600 ha. 


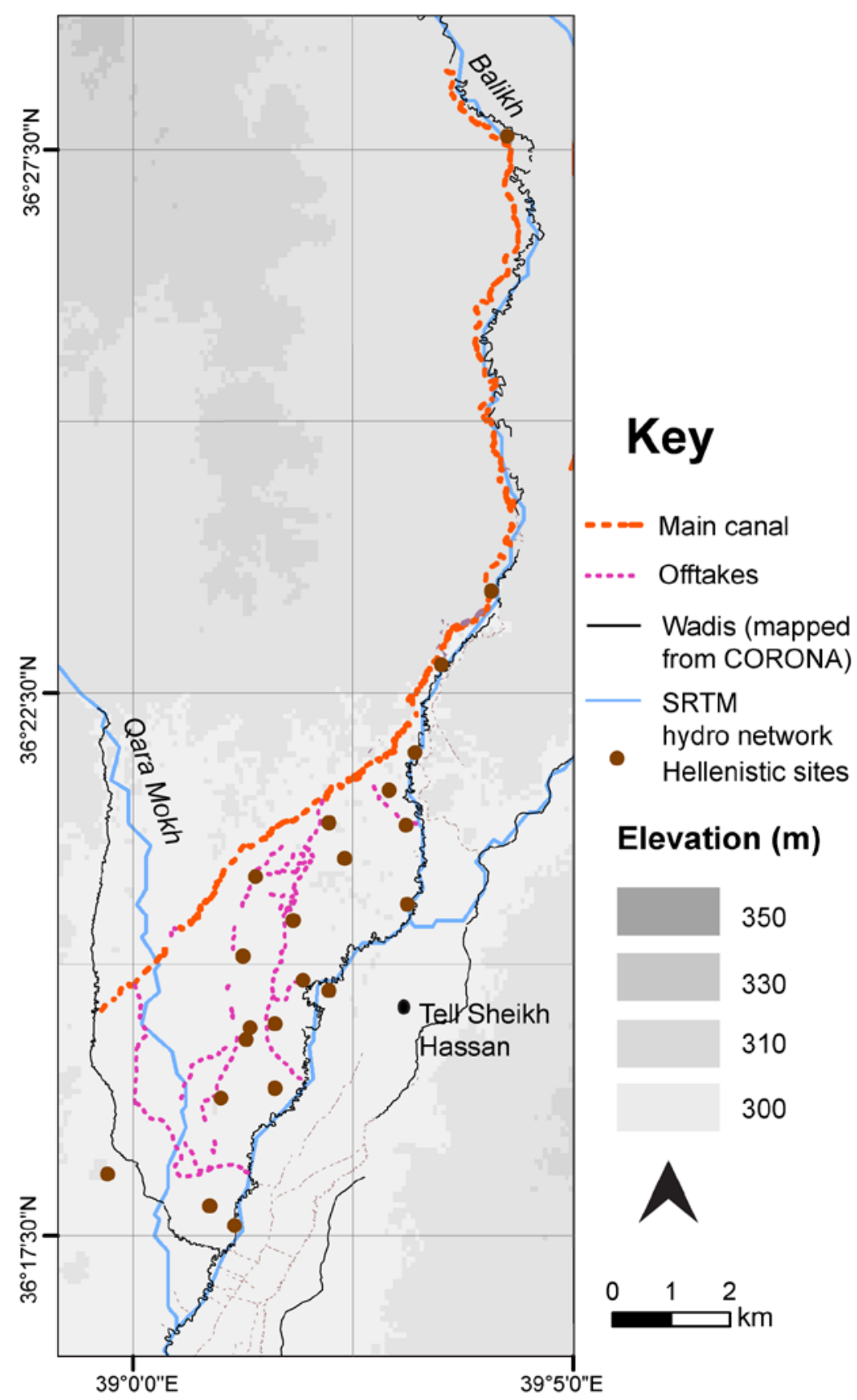

Fig.4 Hellenistic sites and canals. Note the differences in the position of the Qara Mokh (as modelled using SRTM) and the current course of the stream mapped from CORONA.

\section{Early Islamic irrigation}

Much of the evidence for past water management in the Balikh Valley is of Early Islamic date. At this time, Raqqa attained particular importance, including as a capital under the Abbasid caliph Harun Al Rashid. This increased strategic significance may 
have been related to the development of several sophisticated water management systems in the Balikh at this time.

In the north of the valley, possibly overlying an earlier, Bronze Age system, is the Nahr al Abbara. Wilkinson (1996; 1998) recorded and mapped part of it, noting a dry channel represented by a soil mark (Wilkinson 1996 p16). On the CORONA, it is possible to see that a distinct main channel abstracted from the left bank of the Balikh, close to Tell Sahlan, and flowed south-east. In places, a fainter channel on a similar alignment can be discerned in the imagery. The channel then turns southwards, flowing between the Balikh and the Wadi al Keder until it terminates into both these streams. The images also show water entering the system from canalised wadis flowing from the east (the Sluk and Wadi al Keder), past Medinat al Far.

Based on field survey, Wilkinson (1998 p67) linked the system to the Early Islamic period. Because parts of this system continued in use until the $20^{\text {th }}$ century, and because rapid transformation of the landscape did not occur until more recently, this system is exceptionally well preserved on CORONA images of the 1960s. The DEMs (Digital Elevation Models) show how the system made sophisticated use of the natural topography, running the main canal along the highest ground, much like the central Hellenistic system discussed above. This enabled it to attain a gradient of about $0.1 \%$. The offtakes, which included branching submains and laterals, could then flow perpendicularly down the slope, gaining more hydraulic head with gradients of up to $0.5 \%$. 


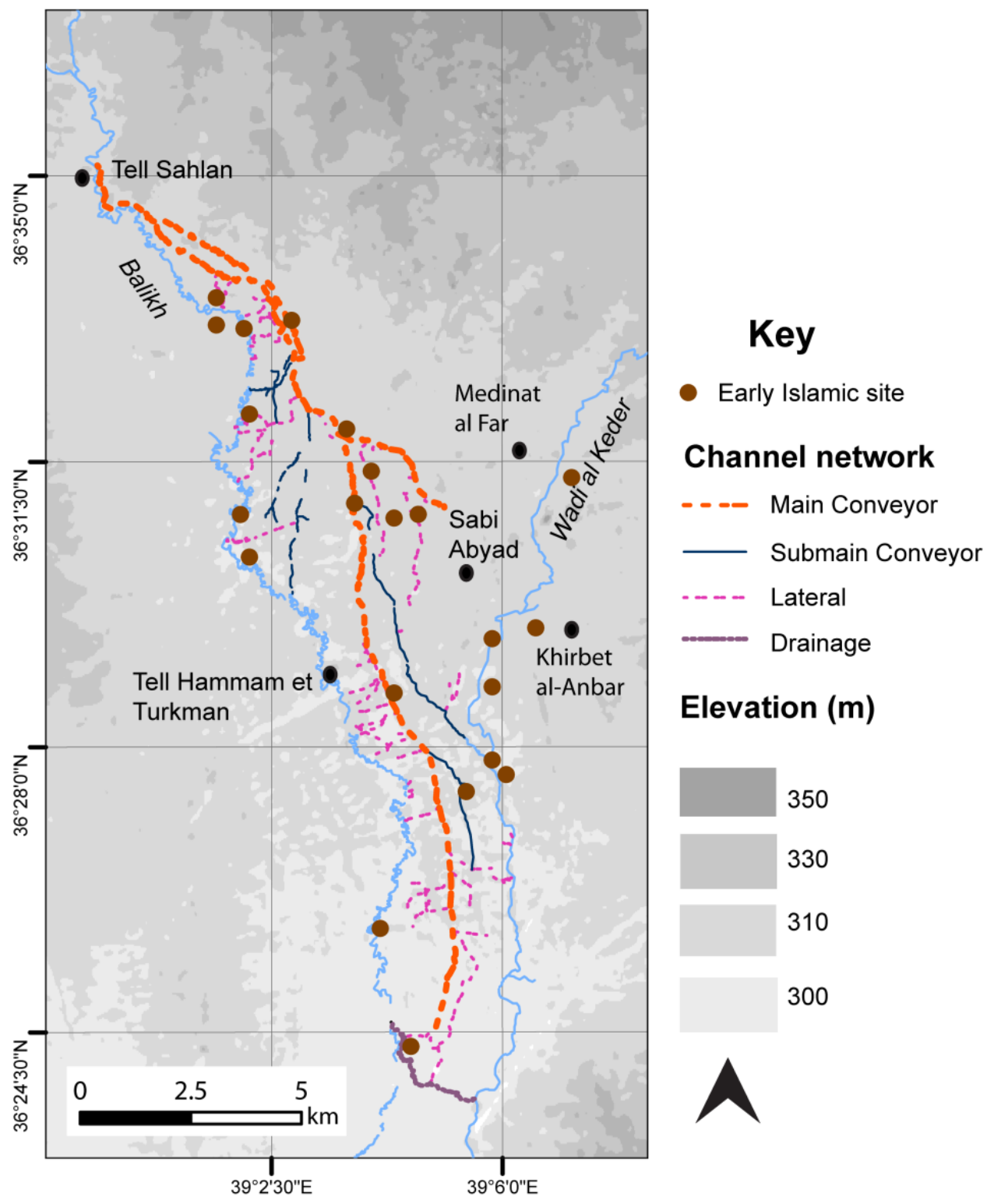

Fig.5 Canals mapped from CORONA and Early Islamic sites as recorded from survey (see Wilkinson 1998; Bartl 1994) in the vicinity of the Nahr al Abbara). 


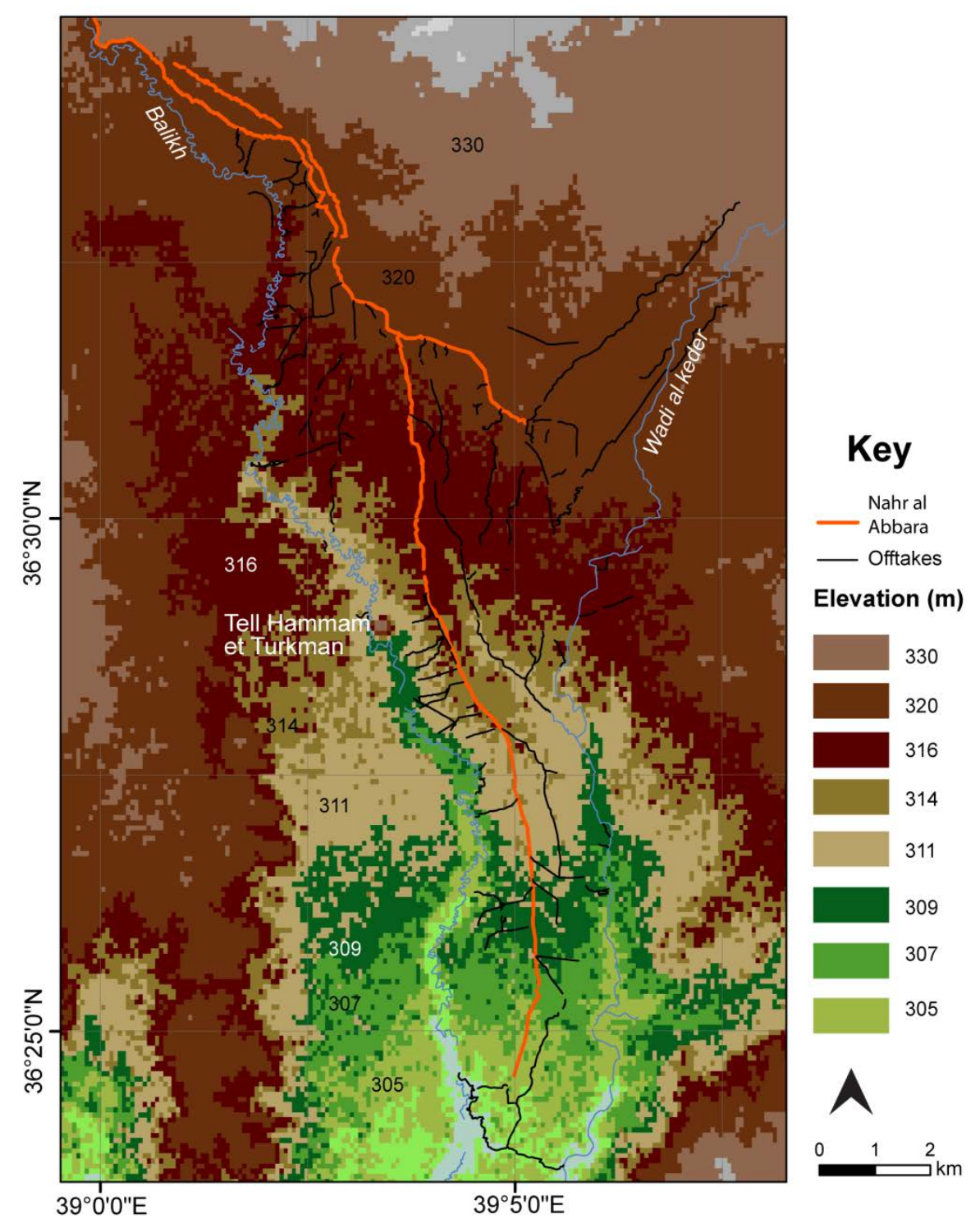

Fig.6 The SRTM DEM (spatial resolution 90m) shows that the Nahr al Abbara main canal flows along a slight ridge, allowing the off-takes to flow at a steeper gradient in this very flat landscape.

Based on the layout of this canal network, it must have irrigated at least 3600 ha in the area between the Balikh and the Wadi al Keder; it was clearly a significant system which would have required some administration in terms of maintenance and water allocation. The low gradient of the valley, which leads to excessive siltation, would have made regular cleaning necessary. Kaptijn's example of the Zerqa Triangle $(2009 ; 2010)$ could open up further discussion of how water rights were managed for the Nahr Al Abbara. The $20^{\text {th }}$ century system in the Zerqa triangle could irrigate up to around 1800-4500 even in a fairly dry month (Kaptijn 2009 p352), with 
water allocated by units of time and divided up between plots by the sheikhs of different clans, with farmers potentially receiving enough water to irrigate c.10 ha of land (Kaptijn 2010 p4). Given the regular layout of the Nahr al Abbara system, it is possible that it could have been managed in a similar way, with each farm using one or two of the offtakes. The entire Nahr al Abbara system and the farms which were supported by it could have been controlled by the nearby Early Islamic sites of Medinat al Far and Khirbet al Anbar (Fig. 4). Historical sources attest to an irrigated landscape in this area at this time (Le Strange 1930 p105) which must refer to the Nahr al Abbara.

There is also evidence for Early Islamic irrigation closer to Raqqa. Heidemann (2006) mapped channels in the area of the site itself (divided into the twin settlements of Raqqa and al-Rafiqa), interpreting these as Early Islamic. The CORONA images were used by the present study to investigate further. While some of the canals truncate Early Abbasid sites, and therefore must be more recent in date, the CORONA shows others that appear to be contemporary with the Early Islamic remains. Several of the open channels supplying the Raqqa area originate from a short qanat to the north (see Fig. 7). 


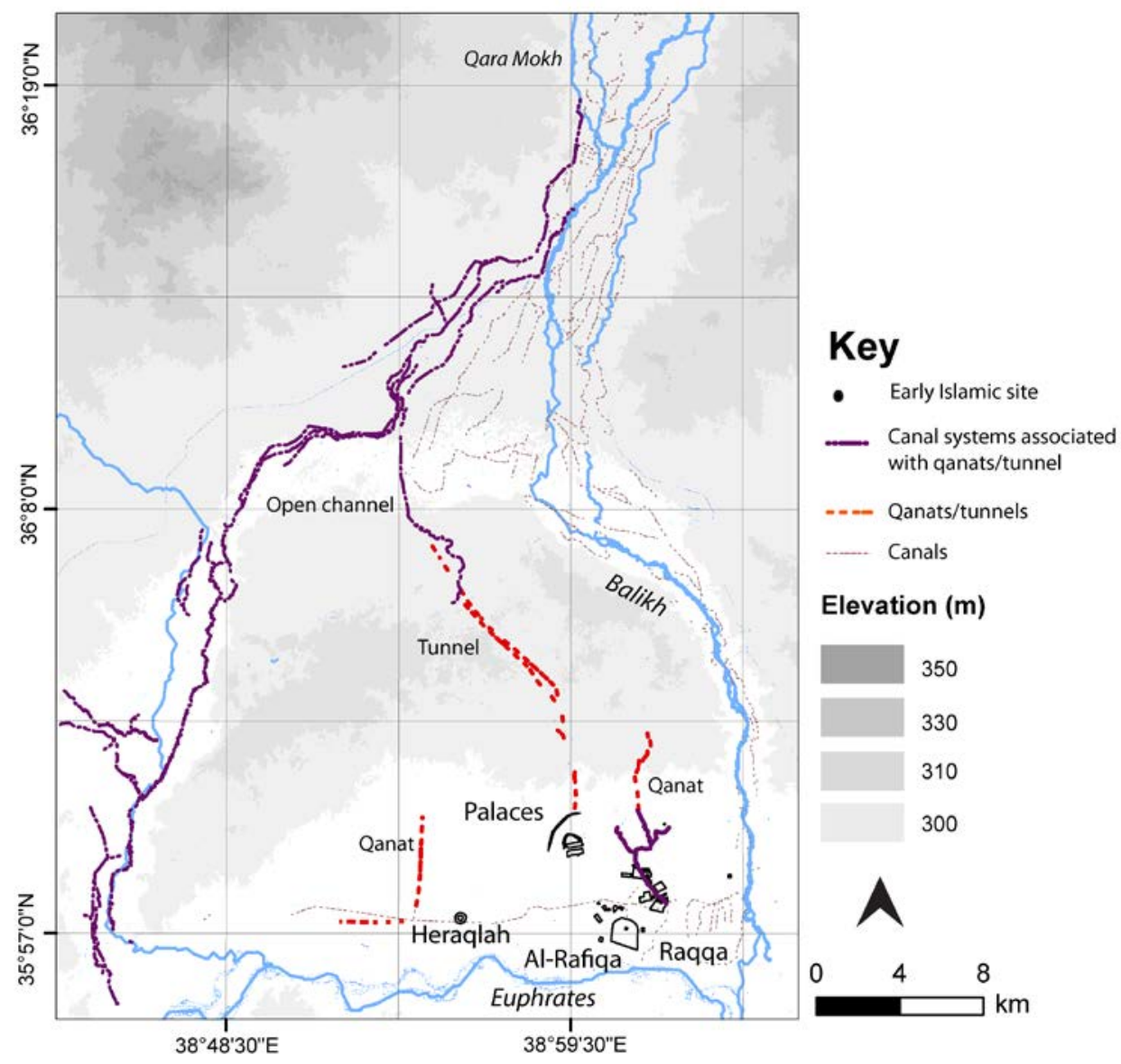

Fig.7 Map of canals in the Raqqa area.

Clearly visible on the CORONA images is a large palace structure (identified by Challis et al 2002-2004 p148; the palace areas are also noted by others e.g. Heidemann 2006, 2011 p49) north of Raqqa. Challis et al (2002-2004 p148) identified several curvilinear features around the palace as canals. However, given that these do not have the hydraulic properties of canals or streams, it is possible to suggest that they may represent a wall or boundary, perhaps as part of a race course, especially when compared with examples from the Early Islamic site of Samarra (e.g. see Northedge 2005; Northedge 2011; Northedge 1990; Herzfeld 1948). However, the palace at Raqqa did appear to have its own water supply, but in the form of a tunnel system (see Fig. 7) which abstracted from canals originating from the Qara Mokh/Balikh c. $25 \mathrm{~km}$ north of the palace. While this originated in an open channel system, it became a tunnel in order to traverse an area of higher ground. On the CORONA images, the tunnel can be traced as a line of dots (Wilkinson and Rayne 2010, Fig. 13), representing maintenance shafts, similar in appearance to a qanat. 
The tunnel appears to be linked to another extensive canal-based irrigation system which extends from the area of the Qara Mokh and throughout the western Balikh horseshoe (see Fig. 7). The channels flow through a valley which may have been formed by a relict confluence of the Balikh with the Euphrates (e.g. see Hritz 2013a). The CORONA images show dense irrigation canals in this area (Rayne, forthcoming, Fig.6). Given their link with the Raqqa tunnel, which in turn is associated with the Early Islamic palaces around Raqqa, the west Balikh horseshoe canals may also have had an Early Islamic phase of use.

These distinct Early Islamic water management systems in the Balikh reflect a peak in irrigation at this time. It is possible that irrigation was encouraged and imposed by the presence of the Abbasid state (also see Rayne forthcoming). For example, during the Early Islamic period, wealthy individuals may be been encouraged to bring new lands into cultivation (Kennedy 2011, p181-182). Extensive canal systems such as the Nahr al Abbara, and possibly also those of the West Balikh horseshoe, provided crops and taxes to support the local, and possibly also the imperial, economy. Raqqa itself was supplied by local, qanat based systems, with a separate water supply for a palace/racecourse complex. This activity represents significant, and highly managed, water abstraction in the Balikh.

\section{Transformations of the landscape}

The successive and complex layers of irrigation in the Balikh, comprising construction, use, abandonment, reuse and modification, were able to transform the landscape and led to the development of new and lasting hydraulic pathways and environmental niches. This included the construction of new channels, the diversion of existing channels, and the formation or drainage of marshes. Landscape changes as a result of water management activities are not unprecedented in Mesopotamia. Much of the research and discussion derives from southern Iraq, where ancient irrigation outflow may have contributed to the development of marshes (see Wilkinson 2012, p124). Marshes in the Ghab Valley in Syria and Amuq Plain in Turkey may also have formed as a response to agricultural activity and would have offered new opportunities for resources (e.g. see Eger 2011 p65, p68). 
Given the complexity of water management in the Balikh, this forms a good case study for investigating human impact on drainage conditions as well as a form of human niche construction. By examining sequences of satellite images and elevation models, and by incorporating archaeological and historical evidence, I will now discuss some of these landscape changes and developments.

\section{Changes to hydraulic networks}

Water management in the Balikh involved changes to the natural drainage networks. This comprised diversion of large volumes of the flow of perennial rivers into artificial canal systems (for example the Sahlan Hammam canal and the Nahr al Abbara system were able to use up to half the base flow of the Balikh), which themselves were later modified, reused, and re-diverted.

In some locations throughout the valley the diversion of segments of streams and wadis into new hydraulic pathways may also have occurred. Comparison is possible between the streams visible in CORONA and later images and those identified using hydrological networks extracted from DEMs (using the ArcGIS hydro tools). The DEMs model the natural stream network, delineating the optimum pixels most likely to channel water, rather than artificial drainages which were later cut deliberately into the landscape. In some cases there is a discrepancy between what appear to be natural streams visible in the imagery and what the DEM network has modelled, potentially revealing stream diversion due to human activity in the past.

Wilkinson $(1996, \mathrm{p5})$ suggests that the Balikh itself may have shifted from a paleochannel west of Tell Hammam et Turkman to its present course as a result of diversion. The point where the Balikh and the Jullab joined may therefore have been further south than their modern confluence. Diversion of this channel could have been an attempt to prevent water from accumulating in the marshes at Waz Gol (see Fig.2), perhaps as a form of early drainage activity. This channel would have avulsed at some time after the Bronze Age (see Wilkinson 1996 p5). It must have attained its present course by the Hellenistic period, based on the dating evidence for the Sahlan-Hammam canal which abstracted from, and closely follows the alignment of, the present course of the Balikh. However, this ambiguity remained because the 
hydro network derived from the DEM identified both the modern Balikh and part of the paleo-channel (see Rayne forthcoming).

One example of possible stream diversion demonstrated by the hydro network is the Qara Mokh. Examination of the CORONA images show a distinct channel into which the central Hellenistic irrigation systems drain, and from which some of the West Balikh canals abstract. However, the modelled optimum drainage route is to the east (as indicated on Figure 4). This indicates that at some stage in the past the natural channel of the Qara Mokh was diverted or possibly avulsed. Given the visible channel's association with the Hellenistic systems, the diversion must have occurred by that time.

In the area of the Nahr al Abbara there is also discrepancy between the modelled drainage routes and several natural, seasonal streams, the Wadi Sluk, Wadi al-Ayuj, and the Wadi al Keder (Fig. 8). The CORONA image (Fig. 9) shows that the Sluk feeds into the Nahr Al Abbara irrigation system, $6 \mathrm{~km}$ south of Medinet al Far. Almost parallel and to the north, a spring fed channel also terminates in this system, cutting through the Early Islamic site. Although to the east of Medinet al Far the Sluk has a natural meandering trace, the segment which drains into the Nahr Al Abbara appears to have been straightened. Parts of the Wadi al-Ayuj, which flows down to join the Wadi al Keder, are also straight; close to Khirbet al Anbar, this stream enters an area which may have been marshy, indicated by multiple sinous, narrow channels and converging wadis. The convergence of the Wadi al-Ayuj with the other wadis north of 
Anbar probably contributed to the development of these marshes.

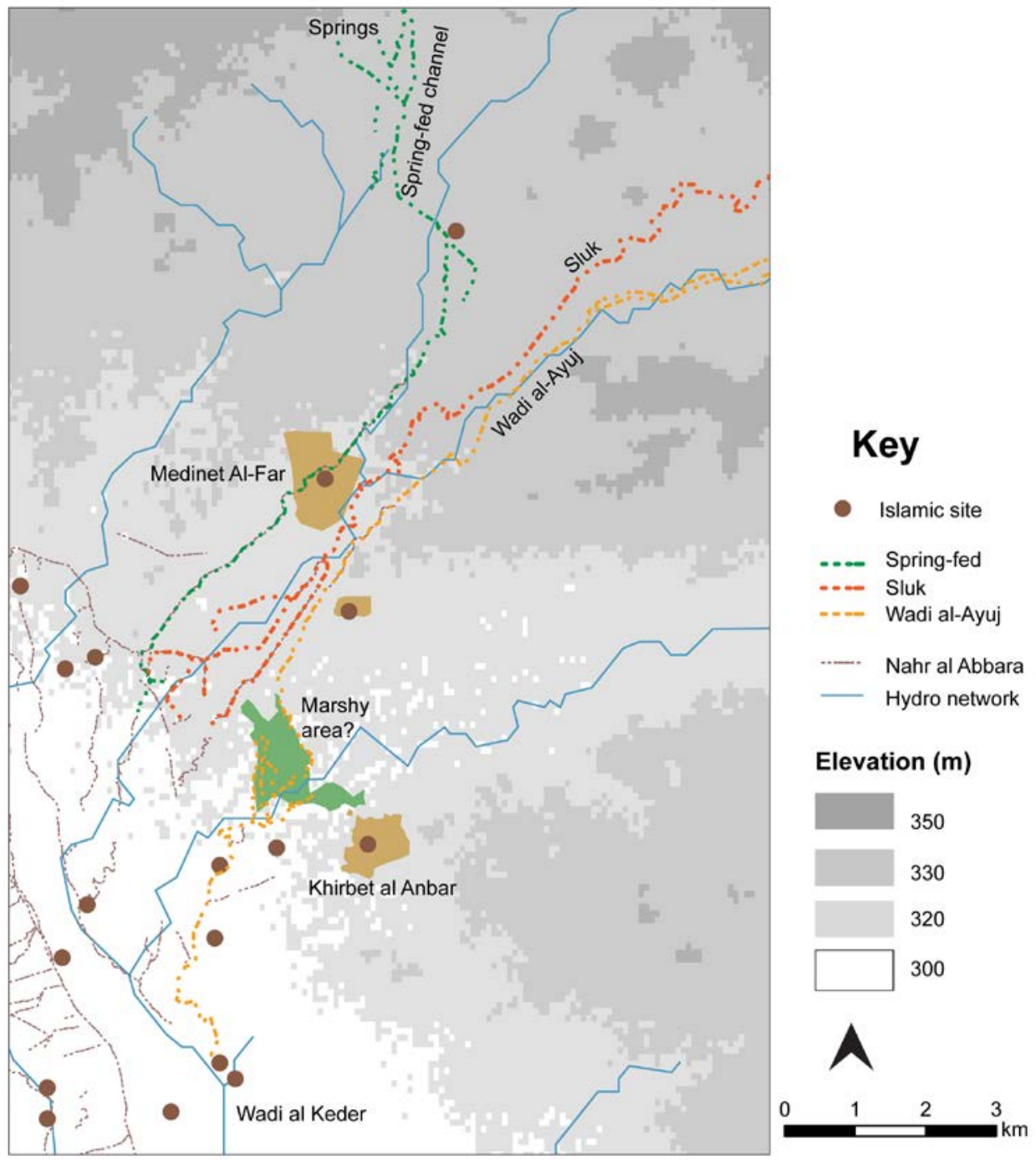

Fig.8 Channels in the area of the Wadi Sluk area which may have been modified in the past. 


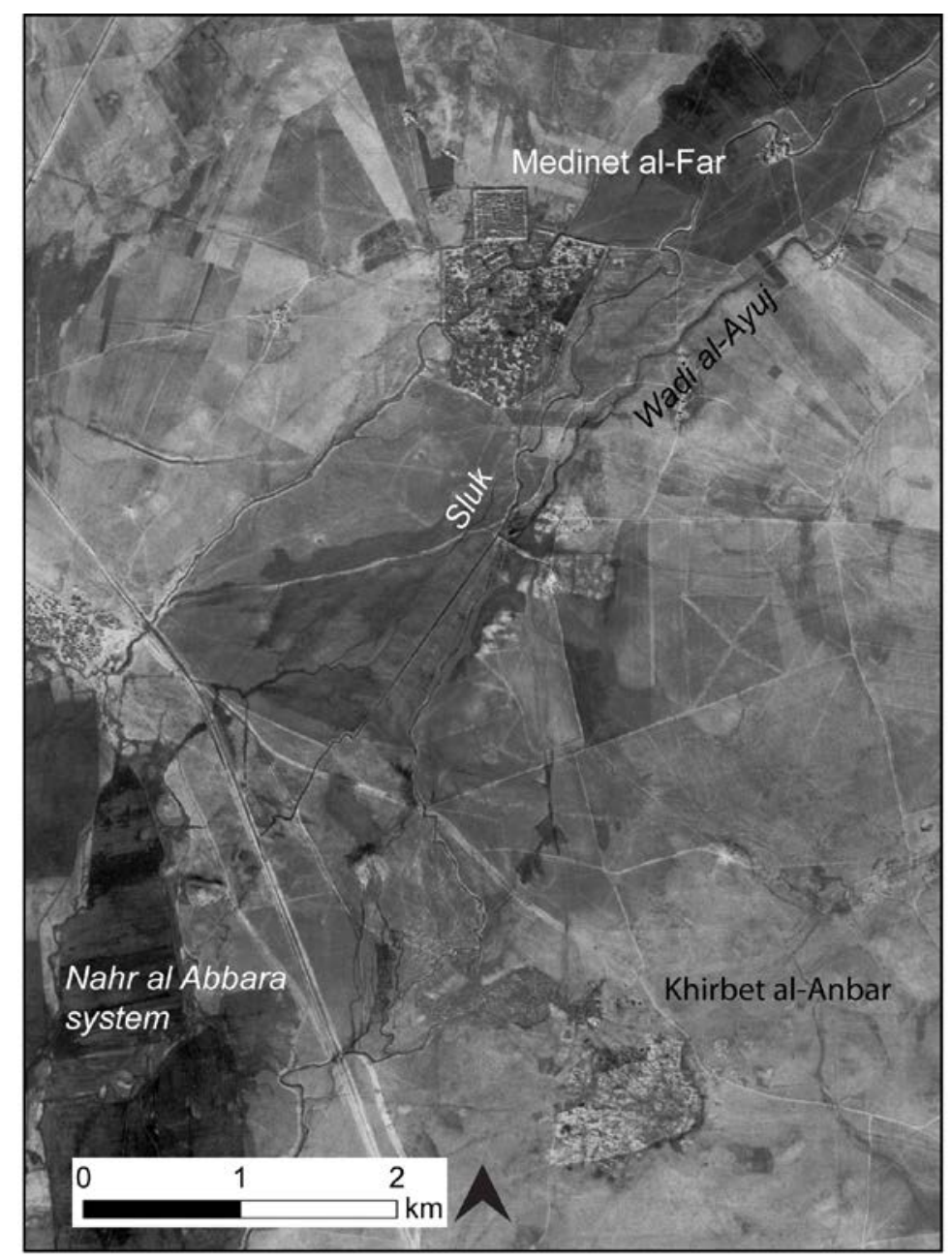

Fig 9: 1967 CORONA image. Canals, wadis and Early Islamic sites are clearly visible.

It is possible that these streams are all natural channels which were modified in the past. Modification could have comprised the diversion of the lower reaches of natural streams into new channels or incorporation into irrigation systems such as the Nahr al Abbara. Channel straightening, which increases the speed of flow through a channel, also appears to have been undertaken.

The hydro model shows that the Wadi al Keder is formed by the waters of some of these streams in the region of the Sluk, and also by an additional stream joining the system about $12 \mathrm{~km}$ south of Medinet al-Far. The planform of this stream's floodplain, which is wide (up to $400 \mathrm{~m}$ in places) and fairly straight, suggests high seasonal flows; at times the wadi could have channelled large volumes of runoff 
originating from the steppe to the east. The channel was used as a drainage point for offtakes from the Nahr Al Abbara, suggesting some possible modifications in the past.

Modification may also have taken place further south, in the area where the Wadi Al Keder meets the Balikh. While the Balikh in this area is almost lost in a complex arrangement of sinuous channels and later canals, the Wadi al Keder is more easily traced; south of Mounbateh, it splits into two channels (these may have been diverted at an unknown date in the past). Wilkinson excavated a section in the Balikh near Tell es Seman (1998, p67), recording evidence that indicated that the river was dry during the Hellenistic-Islamic period. This could have been a result of over irrigation, or perhaps diversion into another channel.

\section{Changes to the water table and drainage properties}

Water management in the Balikh changed the natural drainage conditions, potentially leading to raised water tables, waterlogging and salinity, and marshy conditions, or alternatively draining excess water and diverting it to new locations. Sequences of periodic wetland conditions interspersed with dry periods are a feature of Middle Eastern landscapes (see Wilkinson 2012, p124). Recently, raised water tables in the Balikh were recorded and attributed to poor drainage (Alkhaier et al 2012, p1837), and this was possibly also the case in antiquity. This would be consistent with geomorphological indicators on the CORONA images: Gilgai are depressions and cracks that form in poorly-drained vertisols (Young 1976, p186-187) through differential shrinking and cracking and subsequent expansion, when the soil dries out after irrigation (Mulders 1969, p32).

Gilgai are found associated with the Nahr al Abbara and with channels in the west Balikh horseshoe. These could be a useful indicator of former irrigation specifically strategies which involved leaving large quantities of water onto the fields, or of the discharge of excess water into flood basins. A traditional form of irrigation, 'wild flooding', involves this kind of practice (e.g. see Hansen et al 1980 p201). Ethnohistorical examples of wild-flooding from elsewhere, for example in Arizona in the 
USA (e.g. see Masse 1981, p412; Doolittle 1991, p141) show a similar pattern of channels to examples identifiable in the Balikh.

If this practice was adopted, it would have led to temporary and periodic waterlogging. In these conditions, as the soil dries out, gilgai can form, leading to a wavy/lattice appearance (see Figure 10). Wilkinson (1996) noted the inclusion of freshwater shells in gilgai near the Nahr al Abbara, indicating flooding, possibly as a result of excess irrigation waters (p6-7).

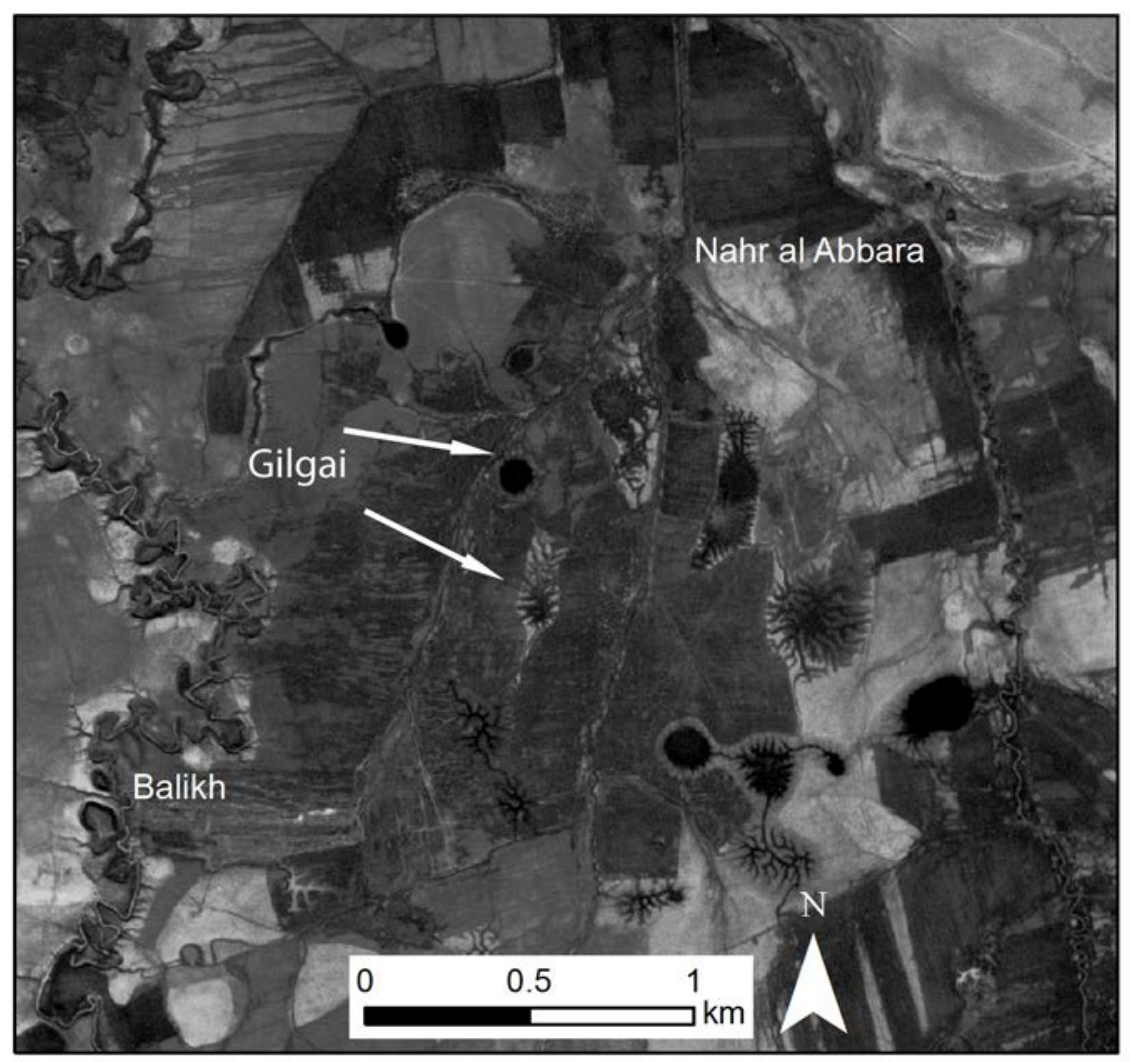

Fig.10 Gilgai in the Balikh Valley near the Nahr al-Abbara. CORONA image from 22 January 1967.

Waterlogged and marshy conditions have been recorded in the Balikh by a number of earlier visitors and archaeologists (e.g. see Sykes 1907, p242). Near Tell Sahlan and Tell Hammam, Mallowan noted marshy conditions which caused difficulty of access to Tell Sahlan (Mallowan 1946, p114, p138). Akkermans also proposed marshy conditions nearby in the Nahr al Abbara area (across the river from the site of Tell Hammam et Turkan) in the prehistoric period (see Akkermans 1993, p206). 
The flat valley is a natural basin for seasonal runoff from the higher land to either side. This would have contributed to the formation of natural marshes in low-lying, poorly-drained areas of branching channels, which may later have been drained due to human action. Secondary marshes would have formed as a result of irrigation outflow.

A natural drainage basin is demonstrated by small lakes visible in the CORONA images $4 \mathrm{~km}$ to the south of Tell Sahlan (see Fig. 1). This area (known locally as Waz Gol) may represent former wetlands. Additional evidence of persistently moist valley floor conditions comes from coring at nearby at Tell Hammam et Turkman which revealed pollen characteristic of 'wet and brackish fields' (Bottema 1989, p14).

While marshy conditions could have constrained settlement, and necessitated drainage provision, they form a useful environmental niche. In southern Iraq there is evidence of the use of plants including sedge, reeds and palms (which grow in waterlogged environments) at Tell Oueli (Wilkinson 2012, p128; Pournelle 2007, p4648). In the Balikh, Mallowan suggests that wildfowl and fish could have been abundant in this particular environmental niche, used as food, and that reeds could have been used as building materials (Mallowan 1946, p113-114). Hritz also refers to these marshes, suggesting that Bronze Age sites made use of them, with settlement near the paleo-channel avoiding these areas and instead being focused on areas of higher ground (Hritz 2013b, p153). Similarly Akkermans (1989, p131) suggests that prehistoric inhabitants in the Balikh would have avoided settling in the swamps in the Nahr al Abbara area, but would have used reeds, waterfowl, fish and molluscs from the marshy areas (Akkermans 1989, p128). The construction of the SahlanHammam system and later the Nahr al Abbara would have changed this subsistence pattern, disrupting the existing drainage routes and possibly diverting water away before it could reach the wetlands. This demonstrates the ability of the later states to impose changes on the environment by modifying existing hydraulic patterns.

In some cases waterlogging can be the result of irrigation practices. There is evidence for marshy conditions in Mesopotamia in Late Roman-Early Islamic times (Wilkinson 2012, p132; Eger 2011). This may have been partly due to an increase in irrigation, which would have diverted water from its natural hydraulic routes and 
allowed outflow to drain into new basins, forming marshes, and also due to changes in land use which led to erosion and increased sedimentation (see Eger 2011).

Patterns of multiple branching channels of the Balikh, wadis and of canals in the south of the valley could be indicative of this. Several irrigation channels of unknown date lead into the top of the horseshoe, which may have experienced raised water tables due to the presence of poorly drained irrigation outflow. Branching and meandering channels associated with relict canals in the West Balikh area suggest similar conditions caused by irrigation. Sykes $(1915$, p311) mentioned marshes in the southern Balikh, describing a lake (Gol Bashi), a canal and swamps. This may be the small lake visible on the CORONA, $2 \mathrm{~km}$ to the north of Tell es Seman (see Fig.1 for location). More recently, raised water tables were recorded in this area (see Alkhaier et al 2012, p1837). Sinuous channels suggesting flooding and a marshy area are also visible in the CORONA near the Early Islamic site of Khirbet al Anbar, associated with possible attempts to control wadis (see Figure 8).

In general however, the construction of large irrigation systems, especially in the Early Islamic period, would have transformed the landscape, bringing formerly marginal land, including marshes and drier areas, into cultivation, and sometimes causing other areas to form secondary marshes due to irrigation outflow. This led to the formation of new environmental niches of large-scale water management and intensive agricultural activity. There is therefore a strong dichotomy between the organised landscape of large-scale irrigation in the later imperial periods indicated by the archaeological evidence and the uncontrolled marshes Mallowan imagines, which he suggests were home to the

'...least enterprising forms of society.... displaced persons seeking refuge in the comparative obscurity of these inaccessible marshlands.' (Mallowan 1946 p115). 


\section{Discussion}

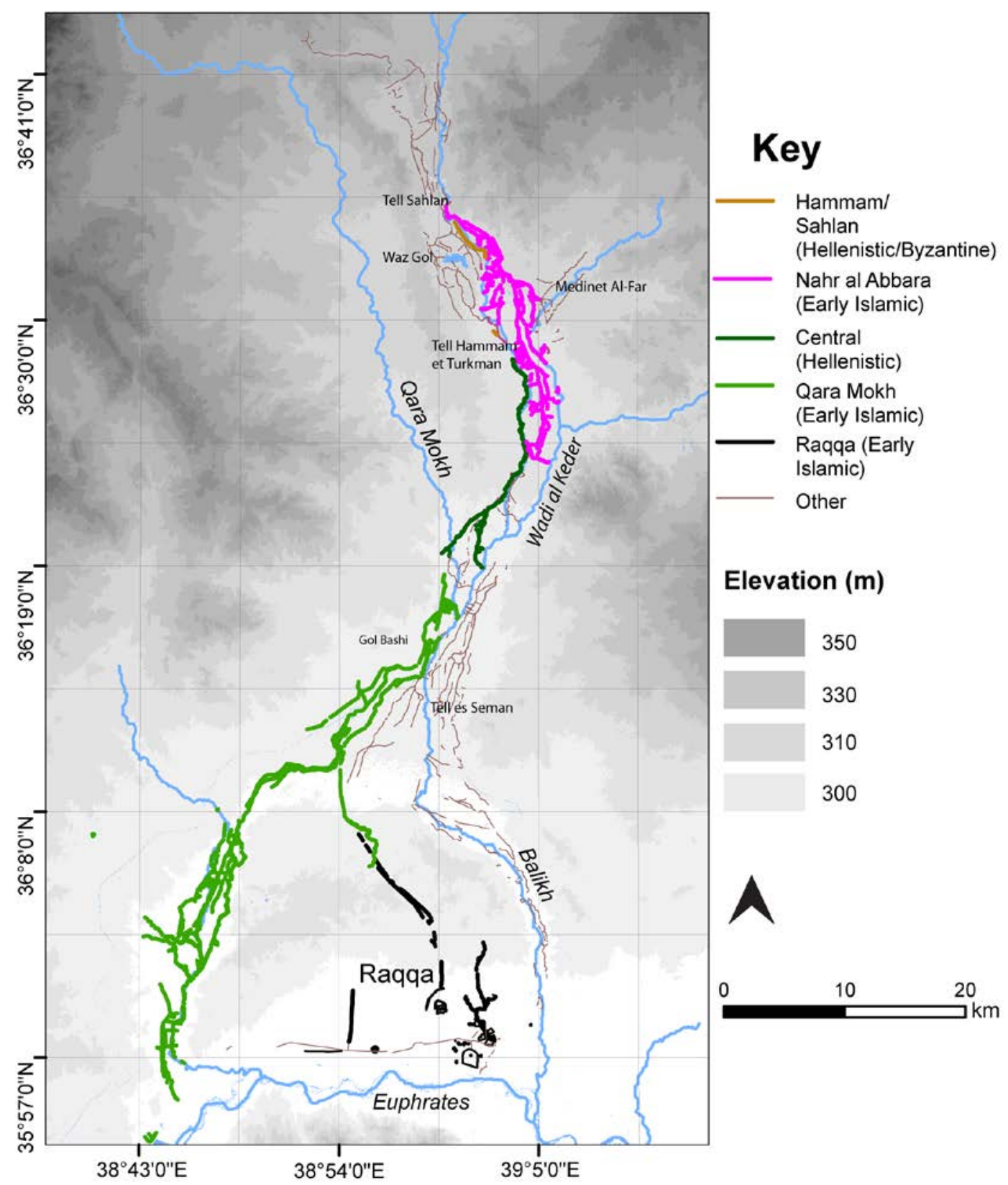

Fig.11 Several separate water management systems in the Balikh Valley could be unpicked from the layers of channels and investigated using DEMs and archaeological data. 
When the remotely sensed evidence is combined with dating evidence from archaeological survey and excavation, a clear development of the agricultural landscape of the Balikh is identifiable; Figure 11 shows the results of this study.

Given the textual evidence from the early second millennium Mari letters, it seems clear that at least some form of water management occurred prior to the classical period. The cisterns mentioned in the Harran census suggest that small-scale water storage was practised by individual farms, presumably with construction and maintenance carried out at this same local level. Water may also have been abstracted directly from the Balikh and diverted onto fields alongside the river.

The water conflict documented in the sources from Mari gives an impression of significant abstraction, however. The base flow of the Balikh was recorded as between 6- $31 \mathrm{cu} \mathrm{m/sec} \mathrm{(Wilkinson} 1998$ p80). For the river's flow to be depleted enough to cause conflict, Bronze Age canals near Tell Sahlan must have been abstracting much of the flow of the Balikh. The irrigated area of the Nahr al Abbara is 3600-4600 ha, which could have abstracted around half the flow of the Balikh, assuming that the Balikh was capable of watering up to 6000 ha (e.g. see Wilkinson 1998 p1). Bronze Age irrigation could therefore have been on a similar scale.

Similarly, extensive irrigation networks in the Hellenistic period must also have utilised most of the available water resources, to irrigate areas of at least 1600 ha in the central Balikh, and also an area of unknown size watered by the Sahlan Hammam canal. As Fig. 3 shows, survey has recorded numerous Hellenistic sites aligned to the canals. If both these networks were separate systems and in use at the same time, the Balikh would have been severely depleted by the time it reached the area of Tell es Seman, possibly disrupting the natural drainage patterns. On the other hand, the seasonal Wadi Al Keder may have continued to flow, having been used to channel runoff and outflow from upstream irrigation schemes.

With similar levels of water management (and occupation activity, see Fig.4) occurring upstream during the Early Islamic period, irrigation schemes south of Tell Es Seman may have needed to rely on other water sources. The canals in the West Balikh horseshoe area seem to have abstracted from the Qara Mokh and to some extent may have relied on the seasonal control of runoff. Raqqa itself and the 
associated palaces needed a reliable water supply other than poor quality irrigation outflow, leading to the construction of the tunnel and the qanat.

By the $20^{\text {th }}$ century these intensive water management activities had declined. Until the 1970s/80s, cultivation predominantly relied on rainfall (e.g. see Hole and Zaitchik, 2006, p145; Beaumont 1996, p137).By the time Gertrude Bell visited (Bell 1924, p55-56) Raqqa was in ruins. Much of the population of the Balikh was not sedentary at this time, relying on pastoralism (see Mallowan 1946, p113). Similarly, Sykes $(1907 ; 1915)$ gives an impression of a less intensively cultivated area in the early $20^{\text {th }}$ century.

\section{Environmental changes and significance}

Before this period of decline, irrigation was able to transform the landscape. By diverting natural channels, and most of the flow of the main permanent water sources in the valley, states from the Bronze Age -Early Islamic period were able to control water resources. This must have resulted in changes to the way water rights were allocated, thereby risking conflict. For example, prehistoric-Bronze Age inhabitants may have relied on the environmental niche represented by the marshes near Tell Hammam et Turkman. When this was later replaced by a large irrigation system, potentially controlled by one settlement or state, wetland resources may have been drained and therefore were no longer available. Significant abstraction in the north of the valley would also have limited abstraction downstream, again changing the way in which agriculture was conducted and controlled.

The ability to control the landscape in these ways reflects the political and economic power of the controller. This may be why a peak in water management activity occurred during the Early Islamic period. At this time, Raqqa was the temporary capital of the empire. The Abbasid policies of bringing formerly marginal lands into cultivation, through tax incentives (e.g. see Kennedy 2011 p181-182) as well as through direct imposition must have been directly related to the large scale landscape changes that occurred at that time. 


\section{Value of remote sensing}

The results of this research demonstrate the value of remote sensing. Currently, fieldwork in Syria is not possible, but remote sensing, when combined with the results of earlier fieldwork, offered a relatively cheap and accessible way to record entire irrigation networks. This enabled a detailed map of relict irrigation throughout the entire Balikh Valley to be constructed. Ancient alignments of water management persisted until relatively recently; for example, while the Hellenistic canals of the central Balikh and the Early Islamic Nahr al Abbara have ancient phases, some irrigation followed on the same alignments into the early $20^{\text {th }}$ century. This longevity reflects the success of these systems in reshaping the hydraulic properties of their landscape.

However, despite the long history of the landscape of the Balikh, rapid intensification in the 1980s transformed it. The Sahlan Hammam canal was investigated in 2010, but no trace of it could be identified. The Nahr al Abbara had been replaced by a series of wells, possibly representing some kind of subsurface irrigation used to water cotton and other irrigated crops. Because they pre-date much recent landscape destruction, CORONA images therefore are often the best tool for recording ancient water management, despite the availability of more recent, high resolution images and elevation models.

\section{Conclusion}

The modern Balikh represents a tightly managed landscape, intensively cultivated with supporting irrigation infrastructure. The survey evidence (e.g. Wilkinson 1998) identified a pattern of numerous small settlements, with a few more significant sites, which the irrigation systems supported. This carefully controlled landscape is not unprecedented, however, as Fig. 11 shows. By the time of the Abbasid Empire, there is evidence that extensive irrigation schemes flowed throughout the valley, with the potential to abstract most of the available water resources. While water management occurred in the Bronze Age, possibly including some reticulated canal systems, the clearest earliest evidence for large-scale abstraction dates to the Hellenistic period. This activity eventually reached a peak in the Early Islamic period. 
The demands of the imperial economy incentivised expensive reorganisation of the landscape. This included the construction of new irrigation schemes and the diversion of natural channels. While irrigation activity made use of the existing landscape, using slight ridges for the location of main canals, for example, it also transformed it, leading to new hydraulic pathways and geomorphological changes such as the drainage and formation of marshes. The imposition of irrigation in the Balikh under Imperial authorities therefore led to the development of new environmental niches which persisted until the most recent phase of transformation. These landscapes, especially in the Early Islamic period, represented intensive food production. The agricultural landscapes also created secondary environments such as marshes and temporary lakes; imperial systems were also capable of facilitating new niches, which could have created new opportunities for resources.

\section{Acknowledgments}

I am particularly grateful for the encouragement and advice of my supervisor Tony Wilkinson. I am also grateful to the Fragile Crescent Project of Durham University for providing settlement survey data and to two reviewers for their comments. I would also like to thank the Faculty of Social Sciences and Health, Durham University, for funding my PhD research.

\section{References}

Ababsa M (2011) Agrarian Counter-Reform in Syria (2000-2010). in Hinnebusch R, El Hindi A, Khaddam M, Ababsa M (eds). Agriculture and reform in Syria, University of St Andrews Centre for Syrian Studies, Fife, p83-109

Akkermans P M M G (1989) The Neolithic of the Balikh Valley, Northern Syria: A first assessment, Paleorient 15(1):122-134 
Akkermans P M M G (1993) Villages in the steppe: Late Neolithic settlement and subsistence in the Balikh Valley, Northern Syria, International Monographs in Prehistory, Ann Arbor

Alkhaier F, Su Z, Flerchinger G N (2012) Reconnoitering the effect of shallow groundwater on land surface temperature and surface energy balance using MODIS and SEBS, Hydrology and Earth System Sciences, 16:1833-1844

Bartl K (1994) Fruhislamische Besiedlung im Balih-Tal/Nord Syrien, Dietrich Reimer, Berlin

Beaumont P (1996) Agricultural and environmental changes in the upper Euphrates catchment of Turkey and Syria and their political and economic implications, Applied Geography 16(1):137-157

Becker A, Finger P, Meyer-Christoffer A, Rudolf B, Schamm K, Schneider U, Ziese M (2013) A description of the global land-surface precipitation data products of the Global Precipitation Climatology Centre with sample applications including centennial (trend) analysis from 1901-present, Earth System Science Data, 5:71-99

Bell G (1924) Amurath to Amurath, Macmillan and co, Ltd, London

Bottema S (1989) Notes on the Prehistory of the Syrian Djezireh, in Haex O M C, Curvers $\mathrm{H} \mathrm{H}$, Akkermans P M M G, To the Euphrates and beyond: Archaeological studies in honour of Maurits N.van Loon, A A Balkema, Rotterdam 
Challis K, Priestnall G, Gardner A, Henderson J, O'Hara S (2004) Corona RemotelySensed Imagry in Dryland Archaeology: The Islamic City of al-Raqqa, Syria, Journal of Field Archaeology, 29(1/2):139-153

Curvers H (1991) Bronze Age society in the Balikh drainage (Syria). unpublished $\mathrm{PhD}$ thesis, University of Amsterdam

De Jong L (2011), Mallowan's Marshes. The archaeology of the Balikh Valley under Roman and Byzantine rule, in Zeitschrift fur Orient-Archaeologie, 4:262-282

Donoghue D N M, Galiatsatos N, Philip G, Beck A R (2002) Satellite Imagery for Archaeological Applications: A case study from the Orontes Valley, in Bewley $\mathrm{R} \mathrm{H}$, Raczkowski W, (eds). Aerial Archaeology: Developing future practice, IOS Press, p211-224

Doolittle W E (1991) A finger on the Hohokam pulse, in Breternitz C D (eds). Prehistoric Irrigation in Arizona symposium 1988, Soil Systems Publications in archaeology 17, Soil Systems, Phoenix, p139-155

Dossin G (1974), Le site du Tuttal-sur-Balikkh, Revue Assyriologique 68:25-34

Eger A (2011) The swamps of home: Marsh formation and settlement in the Early Medieval Near East, Journal of Near Eastern Studies, 70(1):55-79

Kaptijn E (2009) Life on the Watershed, Sidestone Press, Leiden 
Kaptijn E (2010) Communality and power: irrigation in the Zerqa Tirangle, Jordan, Water History, 2:145-163

Kennedy H N (2011) The feeding of the five hundred thousand: cities and agriculture in early Islamic Mesopotamia. Iraq (73): 177-199.

Kendal J, Tehrani J J, Odling-Smee J (2011) Human niche construction in interdisciplinary focus, Philiosophical Transactions of the Royal Society 366:785-729

Kruse E G, Humphreys A S, Pope E J (1983) Farm Water Distribution Systems, in Jensen M E (eds). Design and Operation of Farm Irrigation Systems, American Society of Agricultural Engineers, St Joseph, p395-446

Hansen V E, Israelsen O W, Stringham G E (1980) Irrigation principles and practices, $4^{\text {th }}$ ed, John Wiley \& Sons, New York

Heidemann S (2006), The history of the industrial and commercial area of Abbasid Al-Raqqa, called Al-Raqqa Al-Muhtariqa, Bulletin of SOAS, 69(1):33-52

Heidemann S (2011) The Agricultural Hinterland of Baghdad, al-Raqqa and Samarra: Settlement Patterns in the Diyar Mudar, in Borrut A, Debie M, Papaconstantinou A, Pieri D, Spdini J P, (eds), Le Proche-Orient de Justinien aux Abbasides: Peuplement et dynamiques spatiales, Turnhout, Brepols

Herzfeld E (1948) Geshichte der Stadt Samarra, Hamburg, Eckardt \& Messtorff

Hole, Zaitchik B F (2006) Policies, Plans, Practice, and Prospects: Irrigation in Northeastern Syria, Land Degradation and Development, 18: 133-152 
Hritz C (2013a) A malarial-ridden swamp: using Google earth Pro and Corona to acess the southern Balikh valley, Syria, Journal of Archaeological Science, 40:19751987

Hritz C (2013b) Urbanocentric Models and 'Rural Messiness': A Case Study in the Balikh River Valley, Syria, American Journal of Archaeology, 117(2):141-161

Le Strange G (1930) Lands of the Eastern Caliphate. London, Frank Cass.

Mallowan M E L (1946) Excavations on the Balikh Valley, 1938, Iraq 8:111-159

Masse W B (1981) Prehistoric irrigation systems in the Salt river valley, Arizona, in Science, New Series, 214(4519):408-415

Mulders M A (1969) The arid soils of the Balikh Basin (Syria). unpublished PhD thesis, Rotterdam

Northedge A (1990) The racecourses at Samarra, Bulletin of the School of Oriental and African Studies, University of London, 53(1):31-56

Northedge A (2005) The historical topography of Samarra, British School of Archaeology in Iraq, London 
Northedge A (2011) Sasanian and Abbasid Royal settlement at Samarra: Aspects of continuity and change, in Borrut A, Debie M, Papaconstantinou A, Pieri D, Sodini J P, Le Proche-Orient de Justinien aux Abbasides: Peuplement et dynamiques spatiales, Brepols, p29-43

Pournelle J R (2007) KLM to CORONA: a bird's eye view of cultural ecology and early Mesopotamian urbanization, in Stone E, (eds), Settlement and Society: Essays dedicated to Rober McCormick Adams, Los Angeles, p29-62

Rayne L, (2014), Water and territorial empires, PhD thesis, Durham University

Rayne L, (forthcoming), Early Islamic water management in the hinterland of Raqqa, in Lawrence D, Altaweel M, and Philip G (eds), forthcoming, New Agendas in Remote Sensing and Landscape Archaeology in the Near East: Studies in honour of $T$ J Wilkinson, Chicago, Oriental Institute of the University of Chicago

Schneider U, Becker A, Finger P, Meyer-Christoffer A, Ziese M, Rudolf B (2014) GPCC's new land surface precipitation climatology based on quality-controlled in situ data and its role in quantifying the global water cycle, Theoretical and Applied Climatology 115(1-2):14-40

Sykes M (1915) The Caliphs' last heritage: A short history of the Turkish Empire, Macmillian and Co, London

Sykes M (1907) Journeys in North Mesopotamia, The Geographical Journal, 30(3):237-254 
Toueir K (1983) Heraqlah: a unique victory monument of Harun ar-Rashid, World Archaeology 14(3):296-304

Toueir K (1990) Le Nahr El-Nil entre Raqqa et Heraqleh, Techniques et pratiques hydro-agricoles tradionalles en domaine irrigue, Geuthner, Paris, p217-227

Villard P (1987) Un Conflit d;autorites a propos des euax du Balih, Mari 5:59-96

Wiggermann F A M (2000) Agriculture in the Northern Balikh Valley, in Jas R M, Rainfall and agriculture in Northern Mesopotamia, Nederlnds HistorischArchaeologische Instituut te Istanbul

Wilkinson T J (1996) Sabi Abyad: The geoarchaeology of a complex landscape, in Akkermans P M M G (eds), Tell Sabi Abyad: The Late Neolithic Settlement, Nederlands Historisch-Archaeologisch Instituut Te Istanbul, p1-25

Wilkinson T J (1998) Water and Human Settlement in the Balikh Valley, Syria: Investigations from 1992-1995, Journal of Field Archaeology, 25(1):63-87

Wilkinson T J (2012) Wetland Archaeology and the Role of Marshes in The Ancient Middle East, Pp. 121-39 in: The Oxford Handbook of Wetland Archaeology (Chapter 8), Edited by Francesco Menotti \& Aidan O'Sullivan, Oxford University Press.

Wilkinson T J, Rayne L (2010) Hydraulic landscapes and imperial power in the Near East, Water History 2(2):115-144 
Wilkinson T J, Rayne L (2014), Hydraulic Systems in the Middle East, Selin H (ed), Encyclopaedia of the History of Science, technology, and medicine in Non-Western Cultures, Springer Reference

Young A (1976) Tropical soils and soil survey, Cambridge University Press, Cambridge

Zimmerman J D (1966) Irrigation, John Wiley\& Sons, Inc., New York

\section{Data}

CORONA available from the U.S Geological Survey. See https://lta.cr.usgs.gov/declass 1

The ASTER GLOBAL DEM data was obtained from the online Data Pool at the NASA Land Processes Distributed Active Archive Center (LP DAAC), USGS/Earth Resources Observation and Science (EROS) Center, Sioux Falls, South Dakota (https://lpdaac.usgs.gov/data access

SRTM from USGS (2004), Shuttle Radar Topography Mission, 3 Arc Second scenes, Unfilled Unfinished 2.0, Global Land Cover Facility, University of Maryland, College Park, Maryland, February 2000

Rainfall data from Global Precipitation Climatology Centre (GPCC) http://kunden.dwd.de/GPCC/Visualizer 